\title{
"If it was a state, it has collapsed."1 An examinations of reasons for the collapse of the Late Minoan IA state structures
}

\author{
„Pokud to byl stát, zkolaboval” \\ Testování důvodů kolapsu státních struktur \\ pozdně minojské periody stupně IA
}

\author{
Věra Klontza-Jaklova / Manolis Klontzas
}

\begin{abstract}
The aim of the paper is to discuss how and why the Knossian centralized state system collapsed and, collaterally, the evidence of this collapse is used to infer the existence of a centralized state system in LM IA Crete. LM IA Crete seems to have all the characteristics of an early (primary, segmentary $)^{2}$ state. The Santorini eruption ( $\left.L M I A / I B\right)$ had a direct impact on its fragile structures. During the following period (LMIB), there is evidence for significant disruptions and almost all Minoan centres, even those not on Crete, were destroyed. These destructions appear carefully planned to eliminate as many administrative centres as possible. The main questions of our research are: Can the LM IA Knossian polity be considered as a state? How did it operate? What happened during the LM IB period, which structures collapsed and which survived? We conclude that the centralized power which had controlled almost the whole island during the LM IA period should be considered a state, which collapsed during the LM IB period. The Santorini eruption was the key-factor in speeding up the decline of the early LM I state.
\end{abstract}

\section{Keywords}

State, Collapse, Archaeology of Crisis, Archaeology of Collapse, Late Minoan IA, Late Minoan IB, Minoan polities, Aegean Late Bronze Age, Birth of the State, Late Minoan IB destructions, Bronze Age eruption of the Santorini/Thera volcano, Early State, Primary State

\begin{abstract}
Abstrakt
Cílem přispěvku je diskutovat otázku, jak a proč se knóssoský centralizovaný státní systém zhroutil, a kolaterálně je důkaz tohoto kolapsu použit k odvození existence centralizovaného státního systému na Krétě v období LM IA. Zdá se, že Kréta v období LM IA má všechny vlastnosti raného (primárního, segmentálního) státu. Erupce vulkánu na Santorini (LM IA / IB) měla přímý dopad na jeho křehké struktury. Během následujícího období (LM IB) došlo k destrukcím téměř na všech minojských urbánních centrech, dokonce i minojská centra mimo Krétu byla zničena. Tyto destrukce se zdají být pečlivě naplánovány tak, aby eliminovaly co nejvíce administrativních center. Hlavní otázky našeho výzkumu jsou: Lze považovat "knosskou politii" období LM IA za stát? Jak to
\end{abstract}


fungoval? Co se stalo během období LMIB, které struktury se zhroutily a které přežily? Došli jsme k závěru, že centralizovaná moc, která ovládala téměř celý ostrov během období LM IA, by měla být považována za stát, který se během období LM IB zhroutil. Santorinská erupce byla klíčovým faktorem pro urychlení úpadku této rané, křehké státní struktury.

\section{Klíčová slova}

Stát, Kolaps, Archeologie krize, Archeologie kolapsů, Pozdní minojská IA, Pozdní minojská IB, minojské politi, Pozdní doba bronzová, zrození státu, zánik pozdní minojské IB, erupce vulkánu na Santorini, časné státy, primární státy

Práce vznikla za podpory projektu MUNI/A/0930/2018 „Archeologické terénní prospekce, exkavace, dokumentace a muzejní prezentace VIII"

\section{Introduction: the goal of the paper, and setting the main questions}

The aim of this paper is not to analyze the meaning of the word collapse, nor to debate whether it is a bad or a good phenomenon. However, the terms of reference must be defined: we understand collapse simply as the destruction of any more or less complex structure. It can cover anything from a limited (in time, space, complexity, energy) collapse to general and global collapses. Thus it can refer to anything from the collapse of a single house to the collapse of the whole ecosystem. The size of a collapse can be understood as a relative value dependent on one's point of view; the collapse of a house can represent a total disaster for an individual, though the collapse of Earth's entire ecosystem would be an insignificant event in the history of the Universe. However, a collapse or a catastrophe can have an objective value; its size can be even expressed mathematically (e. g. Saunders 1982, Arnold 1992, Poston - Steward 1998, Sanns 2000). It needs not necessarily represent something bad - some collapses can be very much welcomed by certain elements of society (Pfeiffer 1977, 469-471; Tainter 2009, 260).
A collapse can open a space for new, possibly better, systems, though it does not always do so. Collapse can be what makes history accelerate, driving the historical process ahead. (i. e. Eisenstadt 1991, 241; Tainter 2009, 231; Wallace 2010; Bárta 2011, 43; Charvát 2011) When we speak about the collapse of the Mycenaean palatial system, it is usually presented as a tragedy, as the end of something 'good', followed by a 'Dark Age' (Snodgrass 1971, 2; Desborough 1972, 15-18). Other examples include the "Dark Ages" after the Roman Empire's administration collapsed (Decker 2016). However, this approach simply reflects the ideologies of the pioneers in this field - and maybe even our own fear that we will miss, or lose, something familiar to us, albeit it does not meet our expectations (Sloman 2005, 17-19). The fall of the Mycenaean power centres was probably desired by the majority of contemporary Greek mainland society.

Not all societies have reacted in the same way to identical or similar circumstances, impulses and stimuli. In Crete, for example, the $13^{\text {th }}$ century BC crisis evoked a collective solution, which crystallized in an organized and almost catholic change in the settlement pattern, in which much of the population moved to 
regions that offered strategic advantages (dangerous coast $\rightarrow$ strategic defensible mountainous locations: see Nowicki 2000; Wallace 2010; Klontza-Jaklova 2013, 368-410; Klontza-Jaklova - Klontzas 2019, in press). Many more examples, some disputable, can be presented. From this standpoint, the process can hardly be understood as a collapse at all, despite the disappearance of the previous palatial structure. Saro Wallace describes this process (in the whole Aegean) as a 'successful collapse', which seems to fit well with how we understand the time between LM IIIB2 and the Archaic period. (Wallace 2010; Klontza-Jaklova 2013).

The basis of, and the presumption underlying, our analysis is the acceptance of a general regularity of each collapse process (Tainter 2009, 63-64; Bárta 2011, 23, 29)

Here, we have decided to discuss another collapse; a collapse which probably determined subsequent events up to and including the "successful collapse" of the LM IIIB/C phase. The primary goal of our paper is to discuss how and why the somewhat centralized Neopalatial Minoan system collapsed during the LM IB period, and the evidence of this collapse will be used to infer the existence of a centralized state system in the LMIA phase. In brief, if the consequences of this collapse can be defined, it should be possible to reconstruct what collapsed. In this way, we will contribute to the discussion about the existence of a state structure in Neopalatial Crete, and to the discussion about the importance of studies of collapse mechanisms.

Methodologically, we reverse the usual process. First, we define the collapse in the LM IB period. Based on this definition, we try to reconstruct what structure collapsed, whether it is a state structure or a chiefdom (or some intermediate structure), and finally try to define the form and degree of complexity of the LMIA period on Crete.

\section{Late Minoan Crete: a historical overview}

The LM IB phase is characterized by a chain of destructions of administrative centres; it is the period when the centralized Knossian power seems to have been at its zenith - at least at the beginning of the LM IB phase and the period following the Santorini volcanic eruption, which divides the LM IB phase from the previous LM IA phase. Its absolute chronology is still unclear, due to the much discussed problems of dating this geological event. In brief, conventional data, based on Egyptian historical chronology, dates it to the middle of the $16^{\text {th }}$ century BC, whereas scientific data suggests the third quarter of the $17^{\text {th }}$ century BC (fig. 1; Klontza-Jaklova 2008; 2016). This event had a huge impact on the environment, well beyond the immediate region, and also played a significant role in the socio-political history and the economic developments over a large area (Klontza-Jaklova 2016).

Contemporary scholarship agrees that the palace of Knossos had, in the previous period, managed to unite a large part of the island under its control, and its domain could bel described as a segmentary (decentralized) state (Knappett 1999, 618, 639; Maisels 2010, 193; Klontza-Jaklova 2013, 233-234 ,). The impact of the Santorini eruption on this still very fragile state structure(s) was probably crucial. What exactly happened in Crete after the eruption is one of the most disputed problems of Aegean prehistory (for a summary of recent interpretation models, see Klontza-Jaklová 2013, 190-294; for environmental consequences, see KlontzaJaklová 2016).

During the LM IB phase there are welldocumented destructions at almost all the administrative centres on the island. These destructions are usually, and traditionally, connected with invaders or "conquistadors" 


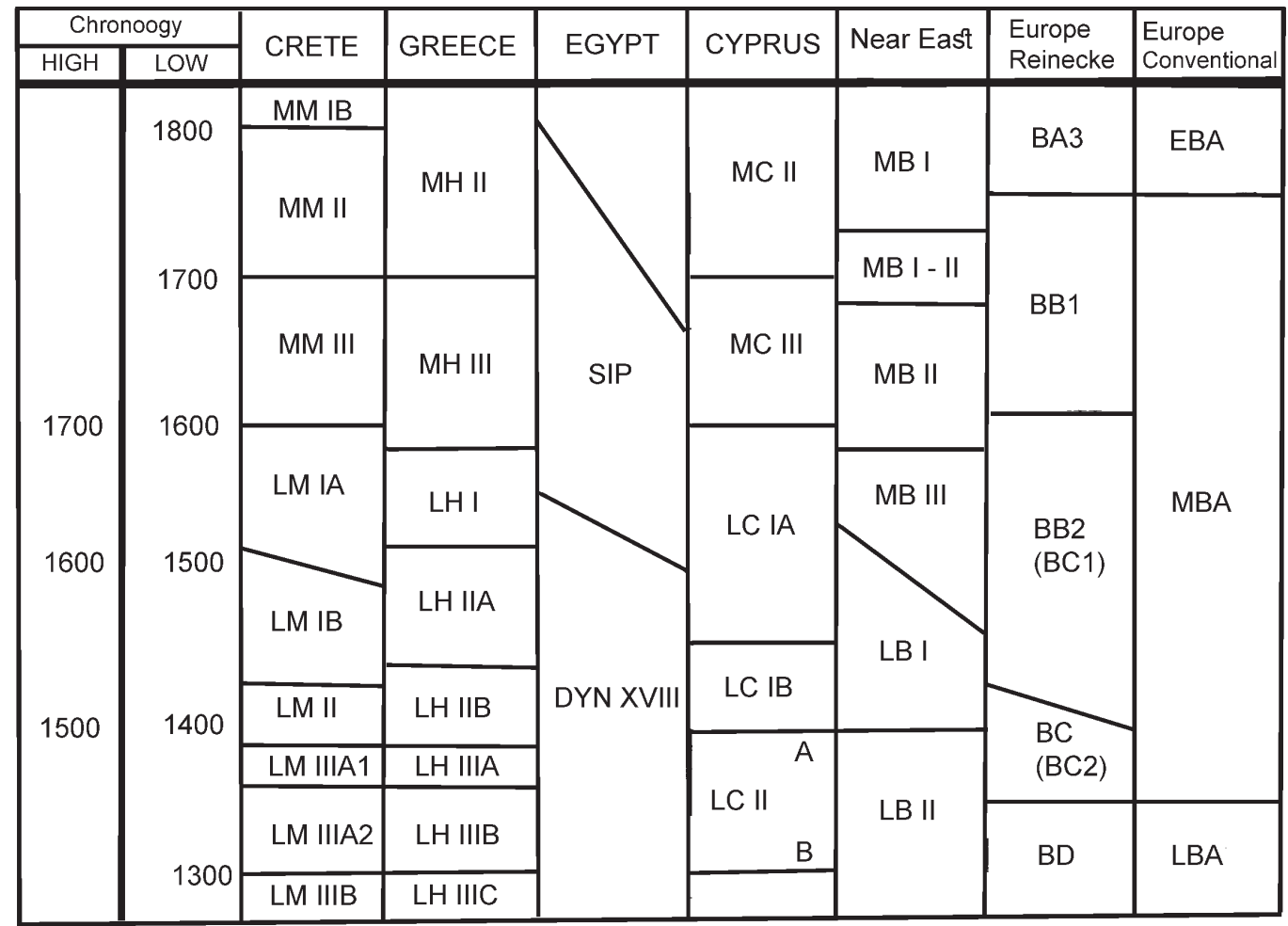

Fig. 1: Chronological chart of period the under discussion MMIB - MMII = Protopalatial period, $M M I I I-L M I B=$ Neopalatial period

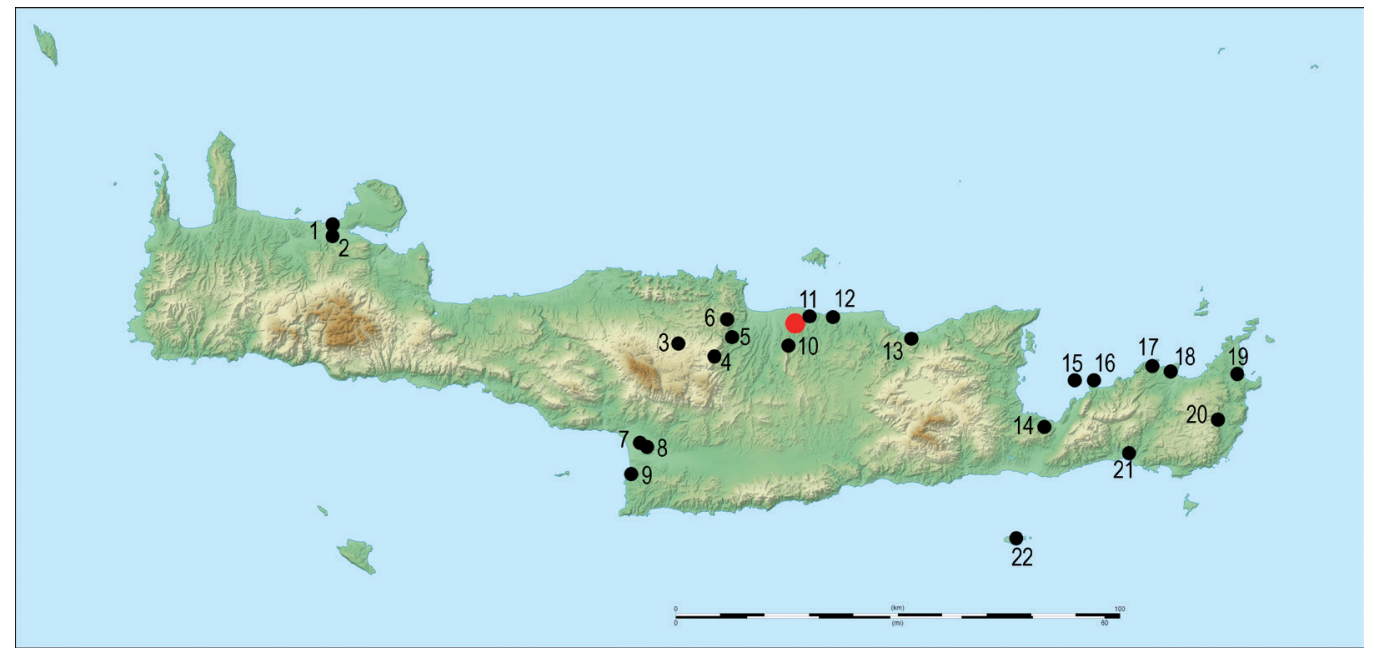

Fig. 2: Crete: sites mentioned in the text. (-Knossos, 1 - Chania, 2 - Nerokourou, 3 -Zominthos, 4 - Sklavokampos, 5 - Tylissos, 6 - Pyrgos, 7 - Hagia Triada, 8 - Phaistos, 9 - Kommos, 10 - Archanes, 11 - Amnisos, 12 - Nirou Chani, 13 - Malia, 14 - Gournia, 15 - Pseira, 16 - Mochlos, 17 - Papadiokampos, 18 - Petras, 21 - Palaikastro, 20 - Zakros, 21 - Makrygialos, 22 - Chryssi). 


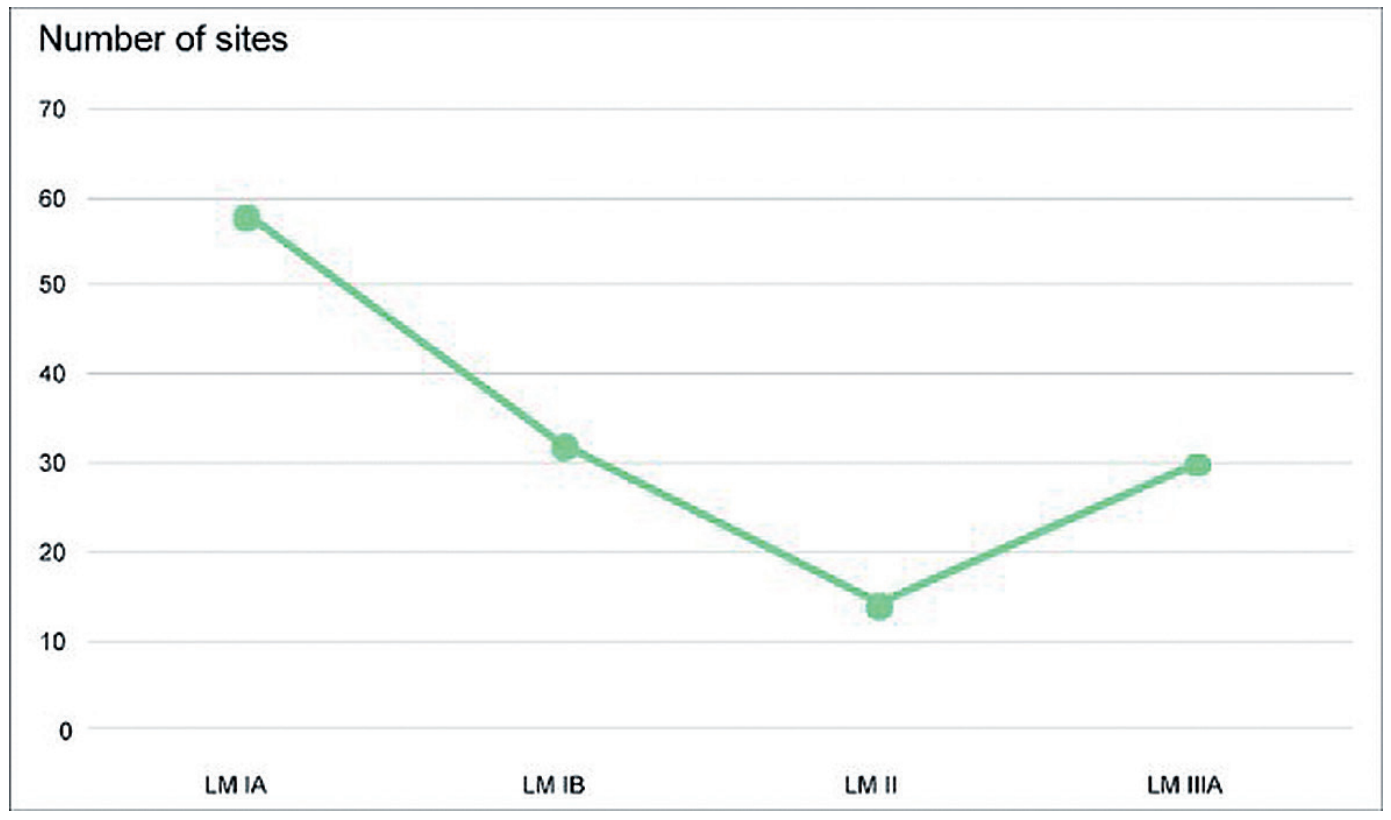

Fig. 3: Declinations of settlements since LM IA to LM IIIA (after Driessen and Macdonald 1997, 36, fig. 34)

from the Mycenaean mainland (Nowicki 2000, 224; Soles 1995; 1999 and personal comm., Wright 2008, 259), or they have been identified as struggles by local rebels against central power, represented by the palatial elites (Pendlebury 1939, 230-231; Cunningham 2007, 42). Jan Driessen and Colin Macdonald (1997, 108) move towards an explanation, first expressed by Nanno Marinatos (1993, 221), that, after the so called Santorini catastrophe, the economic fall was very deep, causing social tensions. However, the crises (economical and systemic) started in the previous period (Driessen - Macdonald 1997, 37). In some cases, these concluded in rebellions accompanied by increased competition among the administrative centres. It is possible that, in certain cases, some direct intervention from the mainland may have played a role. Today the explanations tend to include more reasons, factors and mechanisms (an overview of contemporary interpretations is given in Klontza-Jaklova 2013, 281-294). What can certainly be said is that the destructions of Minoan centres were general and widespread; almost every centre was hit during this period. These attacks were directed at administrative centres, some of which were hit twice. Palaces and other centres, destroyed in the LM IB period, were abandoned for more than 50 years. Crete was heavily depopulated in the following period (fig. 3). The number of LM II settlements is only about one sixth of the number in the early LM I period. After a gap of at least two generations, new settlers started to return to the abandoned and destroyed sites, but they constructed much smaller and simpler buildings over the layers of collapsed urban centres, on the ruins of earlier buildings (Rehak and Younger 2001, 442; KlontzaJaklova 2015). 


\section{Minoan Crete and State: brief history of research}

Discussions about a state system (or systems) in Minoan Crete started in the 1960s, and culminated in the 1990s with the publication of the now classic paper of Carl Knappett (1999) Knappett discussed the possibility of testing the existence of a state system through pottery studies. In the Protopalatial period (MMIA MMIIB), which is the focus of Knappett's study, the five geographical zones divided by three mountain massifs were relatively isolated regions. They were divided into a few relatively independent but competing regions, which can be described as polities. Each of these regions was controlled from one main centre, via smaller centres spread across the territory. These structures of relationships are traceable through material culture.

The question is whether the Protopalatial period could be described as a Chiefdom Confederacy, from which a state can emerge. D. B. Gibon (2011) suggests that it was one of the usual formations which preceded the centralized states. According to him it is a political system which consists of a loose association of towns, villages, or castles/forts (here palaces), united by religion (worshipping common ancestors) and allied politically (Gibon 2011, 220).

In this phase, the new power relations, based on tradition and the communal network, emerge: economic obligations (in the form of tributes or taxes), social rights, obligations connected to armed forces, administration and an ideological system can become established. But in the period precursing the centralized state, the subsistence production is highly decentralized, with the village communities or individual farms scattered across the landscape. Chiefs, kings and, in general, the local leaders are apart from the agrarian substrate and rule through army or ideology (religion). The farmer main-

tains the leader, with his armed forces, through tributes and taxes (Kristiansen 1991, 18-19). It is not a stable situation. Objective and subjective factors act and interact. The emerging complexity can degrade or, if there is sufficient surplus, space is limited and population growth increases, it eventually concludes as a centralized state. In the case of Crete, we believe that the transformation from one stage to the other could be violent and its final stage rapid when one palatial leader and his group had the potential to usurp the power (ideological, administrative, military but mainly economic):

The Protopalatial period ends with destructions of palatial centres deliberately carried out by human forces. An organized uniform rebuilding program followed for all the palatial centres, with the exception of Knossos, where there is no evidence, in the levels of MMIIB - LM IA phases, of destruction initiated by human forces. ${ }^{5}$ Instead, the stratigraphy at Knossos shows total continuity of habitation and function of the palace from LM IA into LM II. (Driessen and Macdonald 1997, 17, 28)

The majority of scholars have usually interpreted this as the beginning of the Knossos hegemony across the island. The presence of a central power exercised from Knossos can be seen in other spheres of society and material culture (the absence of fortification across the island, the sheer cultural dominance, monumentality and size of the Knossian palace, Knossian seals spread across the island, a palatially dominated state, where Knossos is the only palace with a throne, and a hierarchical system of centres). (Driessen and Macdonald 1997, 70, 74; Knappet 1999, 637-638; Younger and Rehak 2008, 150152) 


\section{State or Chiefdom?}

A decision whether the studied structure was or was not a state, must be preceded by a definition of what is, and what is not a state, where chiefdom ends and the state starts. There is no academic concensus on the most appropriate definition. Different criteria evoke different definitions. Here the opinions differ and the discussion in the literature is very rich. Studying the origin and nature of state structures has a long tradition. Understanding the transition from chiefdom to state is not uniform nor is the terminology used in the context of the first state structures.

Terms used include segmentary state (Maisels 2010; Knappett 1999), primary state (Wright 1977, 386), early state (Claessen - Skalnik 1982; Feinman - Marcus 1998), state without adjectives (Kristiansen 1991), Pre-modern state (Blanton Fargher 2008), Prehistoric state (Haas 1982), also Pre-capitalistic state (Marx 1857 (uses also Primitive and ancient state); Moseley - Wallerstein 1978).

Most authors also try to deal with terminology for the border between state and chiefdom (many/all of the authors mentioned above and also: Cohen - Service 1978).

The road to statehood is a very long and complex process. Even forms of chiefdoms are varied (Feinman - Meitzel 1984; Upham 1987; Spencer 1987). Some authors propose abandonment of evolutionary theory but: the majority works with evolutionary perspectives. Various aspects are accented: political economy (D'Altroy and Earle 1985; Earle 1989; 1991), environmental and climatic conditions (Sanders Webster 1978), or structural dynamics (Friedman - Rowlands 1977),

The main criterion is the creation of a stratified society. This represents the crucial structural change for the state evolution process (Fried 1960; 1978; Sanders - Webster 1978; Haas
1982). A chiefdom was rather loosely defined as a polity that organizes and centralizes a regional population. Some degree of heritable social ranking is associated. Chiefs appear where central leadership can provide a social solution to particular ecological, social, or economic problems (Earle 1991, 1-3). Subsistence production is decentralized. The hierarchy of centres does not exist or is very poor. Towns are absent although some regional centres (e.g. palaces) exist. We believe that urban centres can exist without a state but a state without urban centres cannot exist. Chiefs and kings set themselves apart from the agrarian stratum and rule through a retinue of warriors. Regional and local vassals (they may identify themselves as a symbolical brotherhood) and supply the central chief with taxes, tributes and warriors (Kristiansen 1991, 18-19). Such a network is very fragile and highly likely to be restructured (Earle 1991, 6).

But in particular circumstances it can develop into a state. There are many types of states and their development processes vary, they follow some general trajectories but may use different paths.

The crucial element is the centralization of economic, military, and ideological power. Centralization of each of these aspects may develop with varying intensity and speed.

We agree that "the early state is a centralized socio-political organization for the regulation of social relations in a complex, stratified society divided into at least two basic strata, or emergent social classes, whose relations are characterized by political dominance of the former and tributary obligations of the latter legitimized by a common ideology of which reciprocity is the basic principle." (Claessen Sklanik 1978, 640).

According to the literature we can reconstruct the criteria for and common aspects of an early state as follows... In the early state, the 
population is divided into at least two strata: an upper echelon comprising the leader with his direct relatives/aristocracy and a lower stratum of vassals/tenants, largely those who work on the land. The first live in urban centress (or in centres of the first and second level), the majority of the others live in small communities. The position of the supreme leader/sovereign is often based upon a mythical character and a genealogy which connects him with supernatural forces. He is generally surrounded by a court as well as a bodyguard. The aristocracy comprises members of the sovereign's family, clan or lineage heads. The upper class may be completed by priests and, perhaps, specialised traders and skilled warriors. Any private ownership of land is likely to be rare and not important for high social status. But its role would increase with time. The principles of the early state appear to be based upon the concept of reciprocity and reliance on it: all support the ruler with taxes and tributes, or services, while he is responsible for his flock's protection, law, order, and bestowal of benevolence. The priesthood support state ideology and reproduce and propagate the idea of connection of the ruler with the mythological and divine ancestors, and the advantage of the system as given. The ruler is based in the centre which is usually also the cult centre. The administration is established and run by professionals subordinate directly to the leader and rewarded by salary or some equivalentmeans. There is a system of laws and judgments. Punishments are standardized. The army exist for internal and external use. Officially it is to defend the existence of the particular state construction. Some commodities - those most desirable, rare or those which it was essential for the state to controle (luxury goods and strategic raw materials) - may be traded only by the ruler. There is usually a group of professional traders, experts in long-distance trade. Taxation and tributes become systemized, mandatory, and embedded in legal systems with defined punishments. There is then an apparatus to collect and record them, including the executive authorities competent to punish tax offenses. Trade is important but most is still local, food and everyday commodities are traded at a community level and often just exchanged. The extension of trade means that a unified system for conversion of units from different localities has to be established. Membership of a particular rank in society is given by birth. The ruler defines the territory, and is responsible for building state architecture and infrastructure. (Service 1977; Wright 1977; Cohen - Service 1978; Claessen - Skalnik 1982; Haas 1982; Kristiansen 1991; Marcus - Feinman 1998; Blanton - Fargher 2002; Maisels 2010)

\section{Was the LMIA Crete a state?}

The LM IA state in Crete practically never appears in works about early states and their crystallization, although it is cited as the first European civilization. We believe that it is necessary to introduce it into the bibliography as one of the typical examples of the early state; years of archaeological research allow us to reconstruct individual phases of its origin from early stratified society to chiefdom, then chiefdom confederation and eventually the early state (fig. 4).

We have tested if the defined characteristics of the state are traceable in LM IA Crete.

\section{A hierarchy of centres with delegated competencies} In the LM IA period on Crete, the hierarchy of centres undoubtedly existed. Its development and increasing complexity is observable in previous periods. Nucleation of smaller centres (Prepalatial period), crystallization of the first palaces and their territories (Protopalatial period), and eventually a clear "break" at 


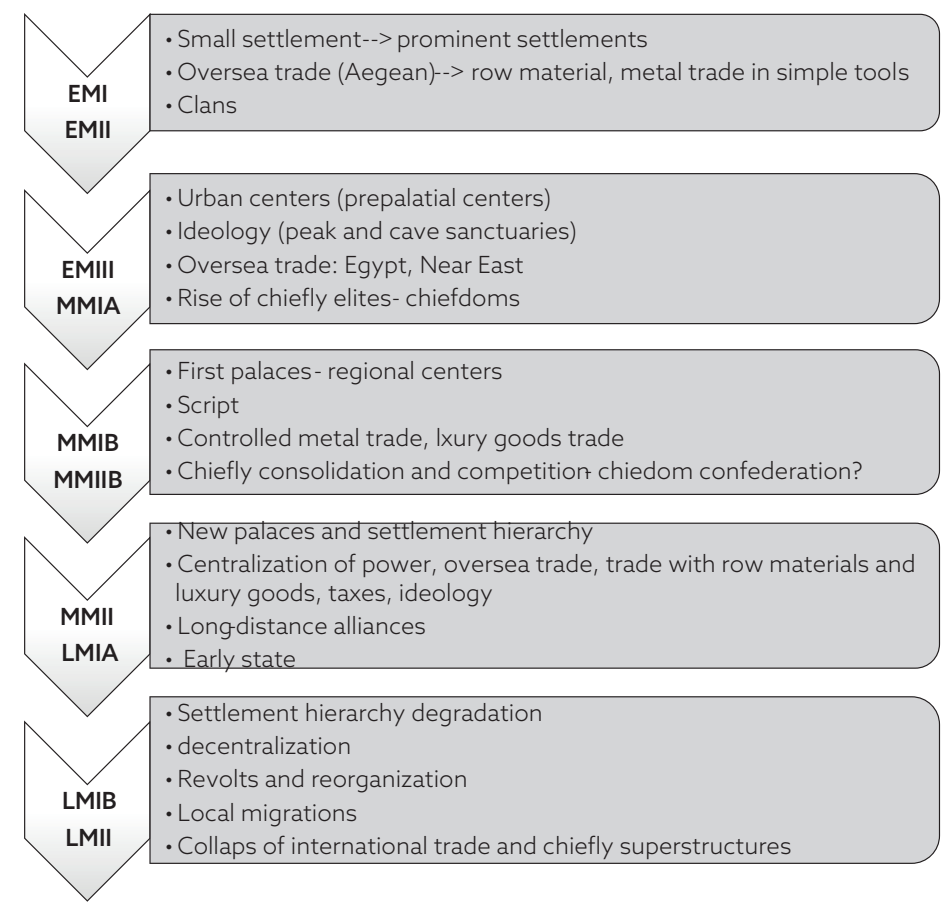

Fig. 4: Transformation of Minoan Bronze Age Society.

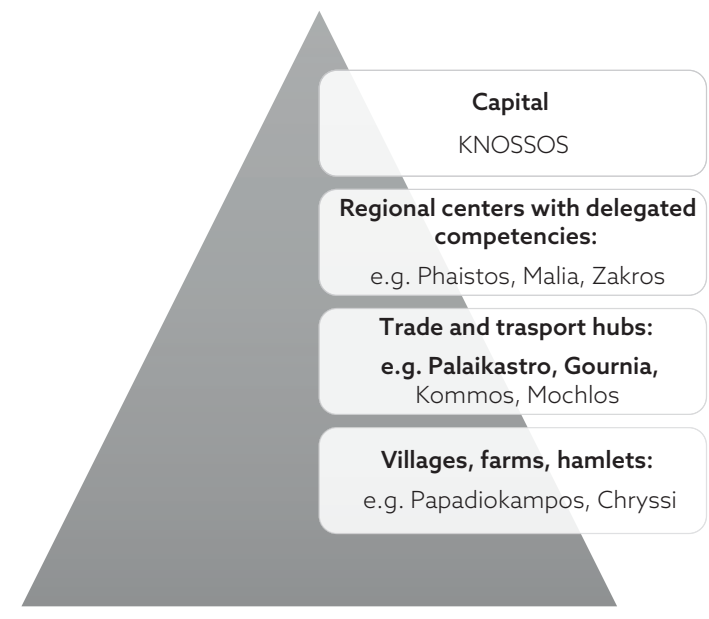

Fig. 5: 4-level hierarchy of the Cretan settlements. 


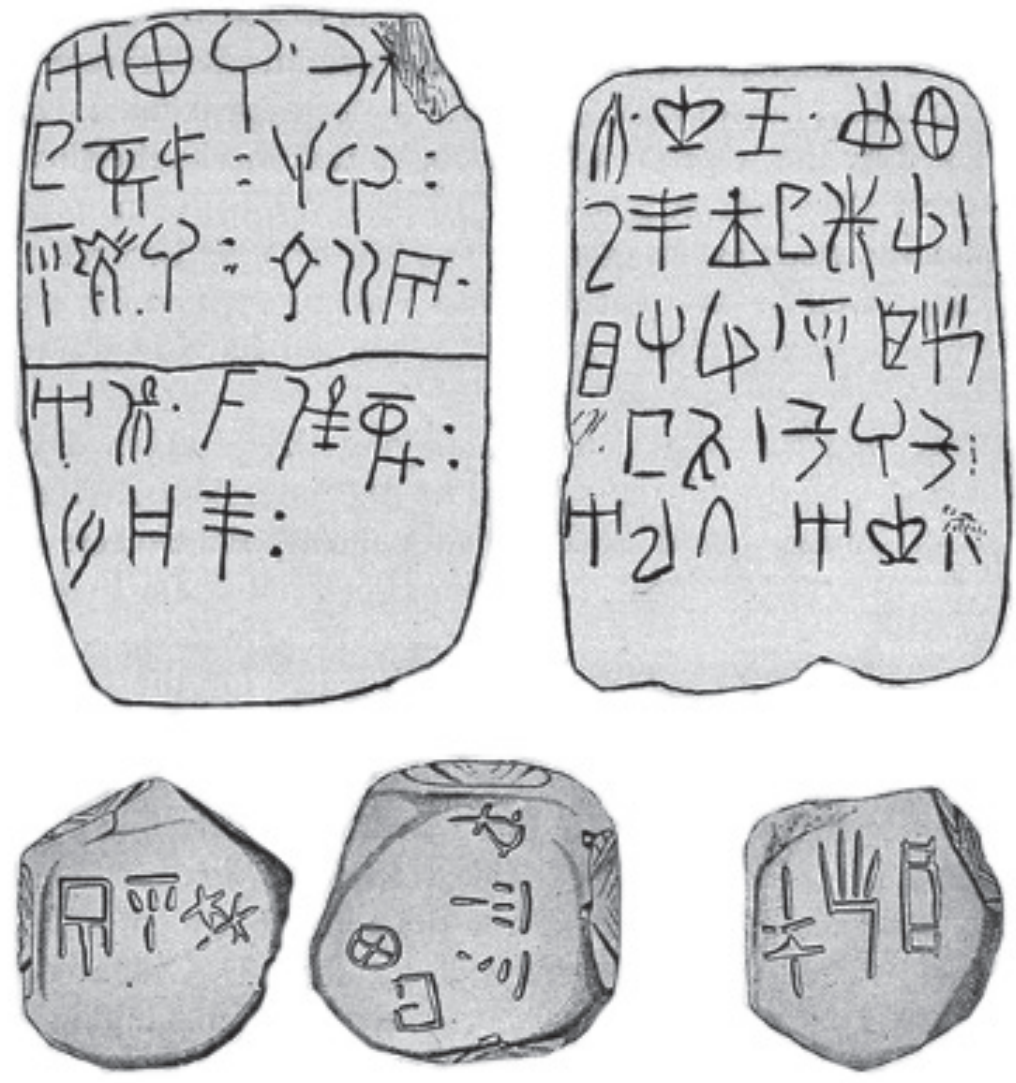

Fig. 6: Inscribed tablets ( $h=10 \mathrm{~cm}$ ) and roundels from Hagia Triada (after Evans 1909, 32, fig. 13)

the moment when Knossos became sovereign (MMIIB). Four different levels of settlement types can be recognized (fig. 5), which some authors consider to be a prerequisite for the existence of a state (Flannery 1998, 16, 55).

Knossos became a capital, a practical and symbolic centre of a united territory, regardless of whether it included the entire island or not. Knossos is also mentioned in Flannery 1998 (22$23,45)$ as a typical palace of the transition period between chiefdom and early state. Second-order centers were palaces, former centres of minor polities that might have formed a free confederation of chieftains during the Protopalatial period (e.g. Phaistos, Malia, Zakros). They were followed by trade centres, local centres, ports (e. g. Palaikastro, Gournia, Mochlos), larger agglomerations with palace elements, sometimes referred to as villas (e. g. Tylissos, Archanes), agricultural settlements, peripheral settlements, farms, farmhouses, fishing villages, and so on.

\section{Administration and taxes}

The central palace housed the ruler, his family, administration offices and people serving the cult. It was not only the centre of the "government" and united cult, but also the centre where the collected taxes, luxury production and bulkmetal were held. Here, there was also a central archive documenting tax procedures. 

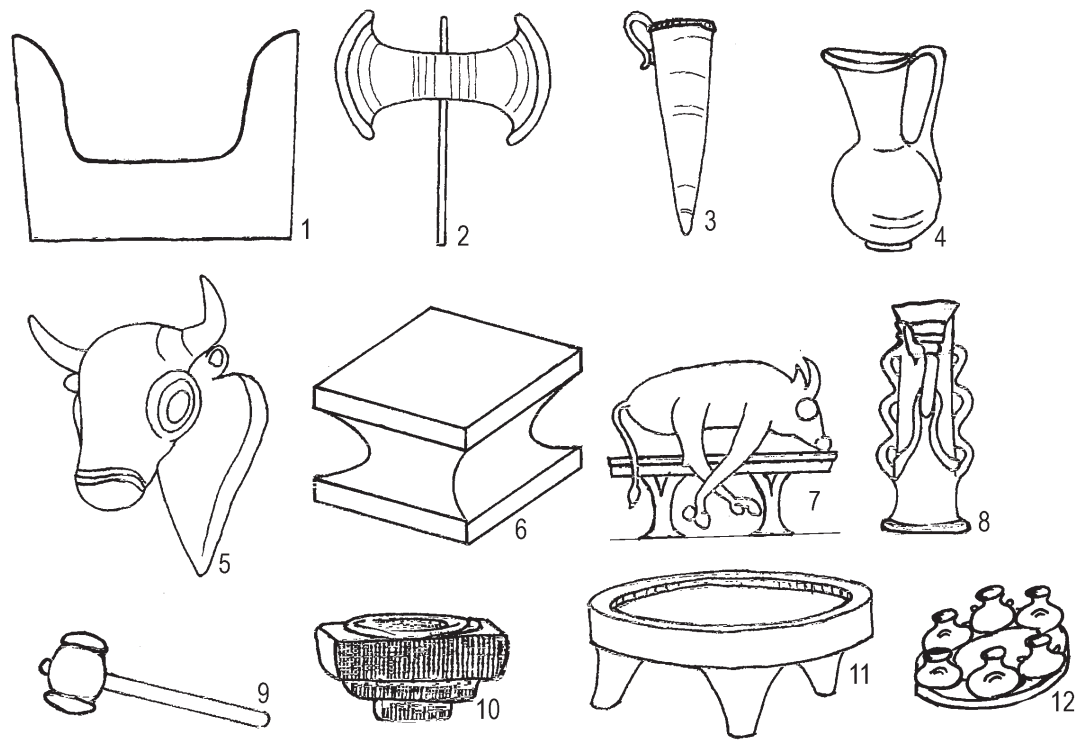

Fig. 7: Minoan cult equipment: 1 - horns of consecration, 2 - double axe, 3 - rhyton, 4 - jug, pitcher, 5 - animalhead-shaped rhyton (or shell-shaped rhyton), 6 - incurved altar, 7 - scarification table, 8 - tubular base, 9 stone maces, 10 - libation altar, 11 - offering table, 12 - kernos (after Marinatos 1990, 5 -7, fig. 3-13).

On the basis of parallels with later Mycenaean sources and despite the fact that linear A script has not been deciphered, current research is certain that taxes were collected and they were collected in Knossos. Clay nodules, tags and tablets clearly illustrate the counting and recording of commodities (fig. 6).

\section{A state ideology}

State ideology can be demonstrated by the uniformity of shrines, the manifestation of the cult in material culture. Palace ceramics distributed to second-order centres carry the same symbolism (lily blossom, double axe, etc.). Ritual tools (rhytons, double axes) are standardized. Small shrines of the previous period are extinct (fig. 7).

\section{A military establishment}

There was a long-standing opinion that there was no military component in Crete or that it was very limited. Current opinion within Aegean prehistory, however, no longer doubts the existence of organized military forces in Neopalatial Crete (Molloy 2002), as evidenced by the finds of weapons and iconography (e.g. West house, Room 5, North wall: Assembly of the troops on the Hill and Shipwreck, Doumas 1992, 58-61, Fig. 26-29) and indirectly also documents of military activities (organized destruction of settlements, construction of fortifications, which surely required a guard) (fig. 8).

The Cretan state system, or Knossian power, also had a policy of expansion. There were colonies or emporia on Cycladic islands directly established by Minoans. There were also Cycladic centres, which adopted or accepted the Minoan administration system. (Younger - Rehak 2008, 140; Klontza-Jaklova 2013, 137-138, 192) (fig. 9). 


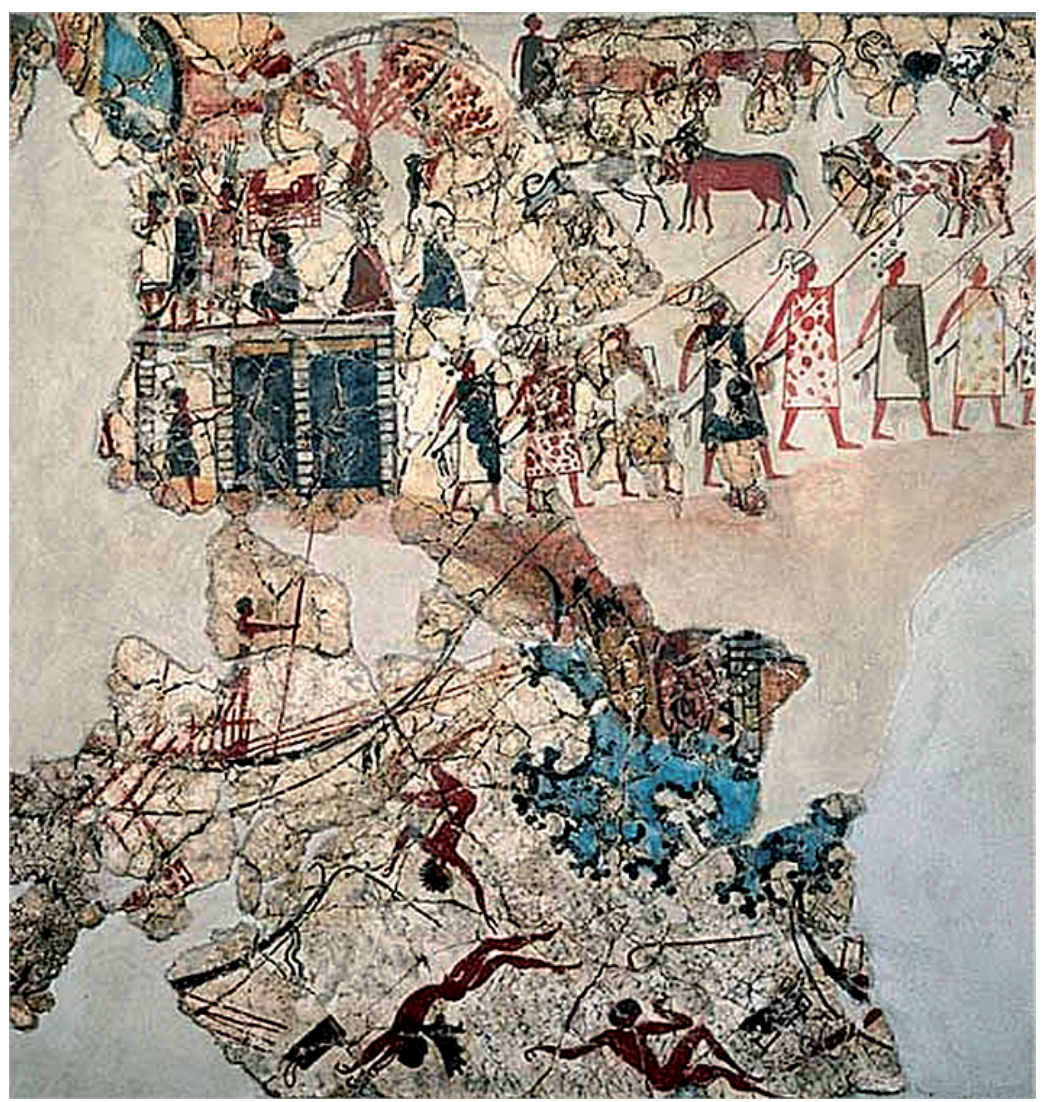

Fig. 8: Akrotiri (Santorini/Thera), West house, Room 5, North wall: Minoan warriors (after Morgan 1990, Table A)

\section{Long-distance trade}

Crete's trading activities reached distant regions including Egypt, Mesopotamia, Northern Aegean, Cyprus, Asia Minor. How exactly this overseas trade was organized, remains a matter of question due to the absence of written sources. Some Mediterranean centres (e.g. Avaris, Tel Kabri, Alalakh) were decorated with frescoes in Minoan style, and it is accepted that they were made by Minoan painters. This, according to orientalists, presupposes a bilateral agreement of equal partners (fig. 10). E.g. Mycenaean palaces had a monopoly in the trade and redistribution of metals, with the management of metal trade and craft. It seems that the Minoan metal economy was organized differently. There are bronze ingots and metal workshops in the Minoan centres, so the question is whether the metal workshops in the second and third order centres were allowed to operate independently, were delegated from the capital.

\section{Laws and regulations}

We lack the evidence of the existence of laws and regulations, but they can be assumed by analogy with slightly later Mycenaean centres. E.g. records of legal dispute over land are known from the Pylos palace archive (Shelmerdine 2008, 300-301). 


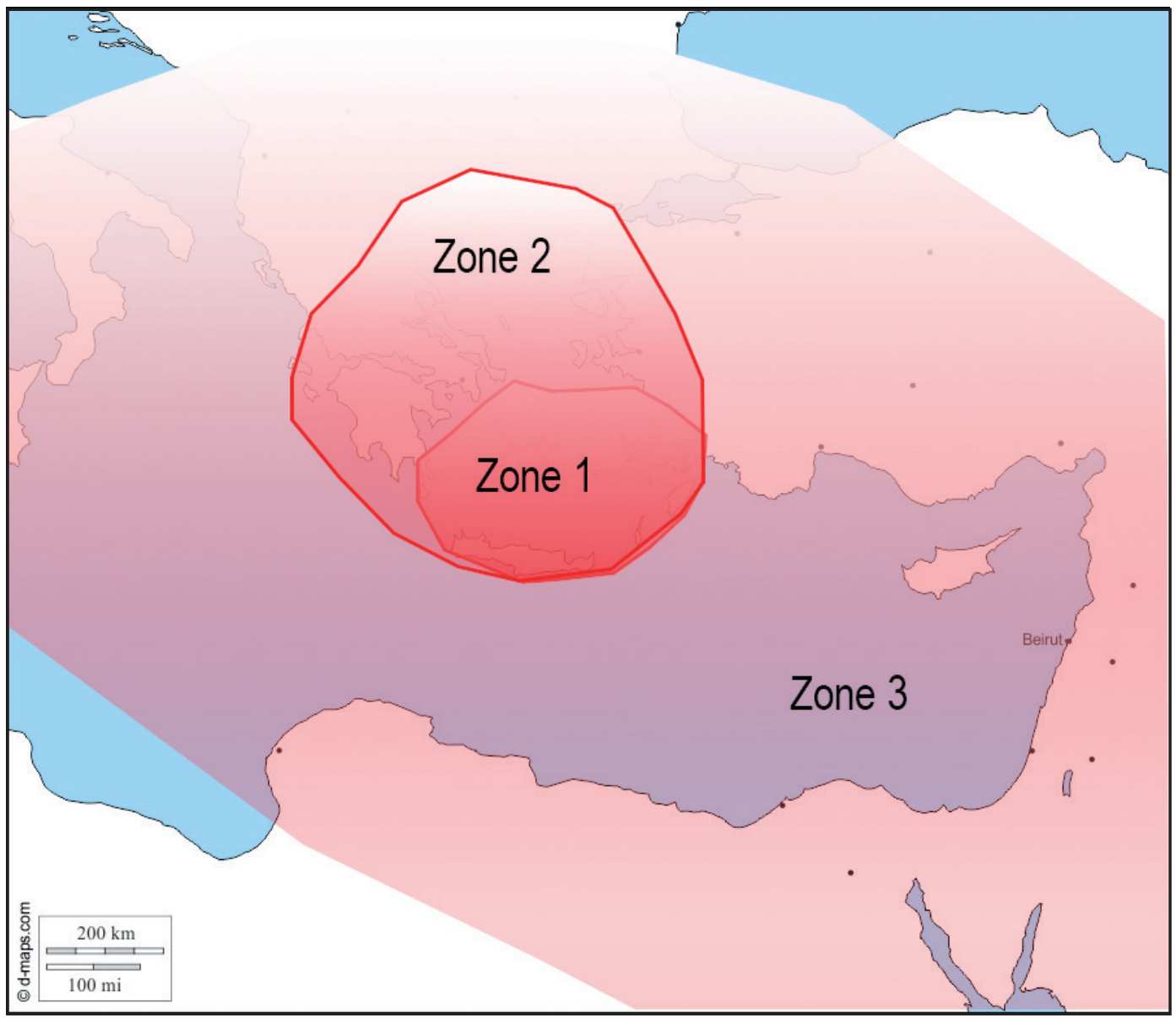

Fig. 9: Spheres of influence of the LM IA- LM IA/B (Knossian) power. Zone 1: habitation zone, Zone 2: significant Minoan influence, Zone 3: Trade and diplomatical conntacts. (After Melas 1988; Wiener 2013)

\section{A “monetary" system.}

Here we mean that there was a unified system which set the 'cost' of strategic materials. There were standard measures of weight, likewise, of size for bronze ingots, and measuring scales have been found (Michailidou 2001a; 2001b; Younger - Rehak 2008, 151-152;, Klontza-Jaklová 2013, 221; fig. 11)

\section{Foreign affairs and diplomacy}

It is possible to rely on documents from Egypt. The Minoans are identified as the Keftiu of
Egyptian sources from the early New Kingdom. They seem to be vassals of the Egyptian pharaoh. They are mentioned in sources from the postSantorini eruption (LM IB). Hyksos Egypt, concurrent with LM IA Crete, left virtually no narrative written sources. From this period comes the find of a stone lid with King Khayan's cartouche found in Knossos (Karetsou - Andreadaki-Vlazaki 2000, 82-83; original publication: Evans 19211935, I, 419, fig 3014a, b), which could also be an indicator of diplomatic and cultural relationships between Hyksos and Cretan rulers. This 


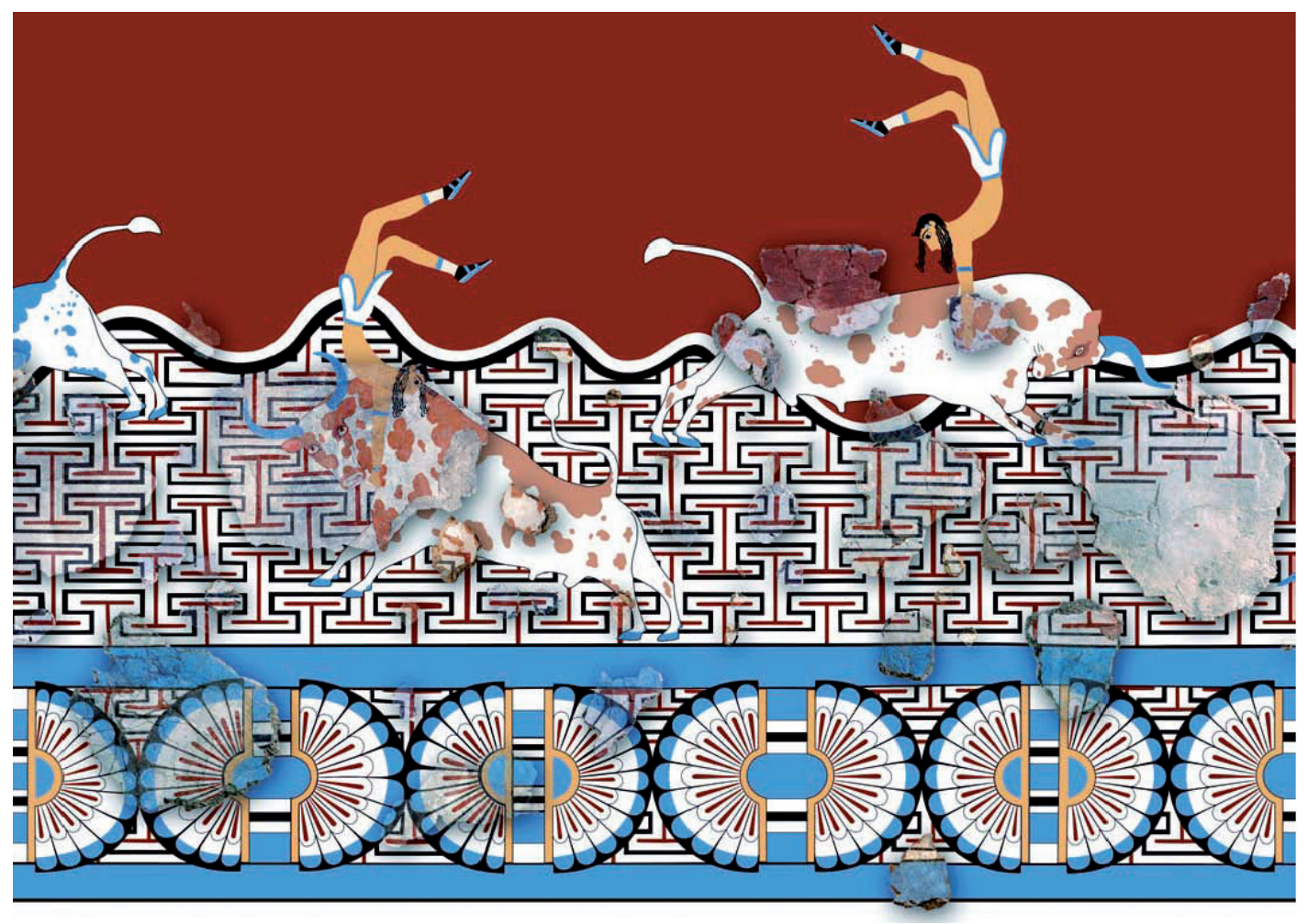

Fig. 10: Avaris/Tell el-Dab'a (Egypt): Reconstruction of the Bull Fresco in Aegean style (after Bietak et al. 2007, fig. 59)

category would also include the aforementioned exchange of artists.

\section{Hard and soft infrastructures}

Furthermore, central power invested in hard infrastructures such as roads. Soft structures such as education or social systems are not proven archaeologically, but it can be assumed that people working in the administration had to have some systematic education that probably took place in palaces.

LM IA Crete had all the characteristics of an early state.

This system, this early state, was certainly very fragile, and the Santorini eruption (LM IA/IB) had a direct and, as we will argue below, a fatal impact on it. Although the physical impact on the Cretan ecosystem was not totally disastrous, the political system was not able to survive. Diseases, water contamination, the effect of the tsunami on the north-east coast, crop failures, fear, and disruption of marine routes were problems which were beyond the limits of Knossian centralized power. It gave opportunities to political rivals from smaller centres, and supplied the impulse for the dissatisfied lower strata of society to express their demands (Driessen - Macdonald 1997, 113). (for more about the Santorini eruption, see KlontzaJaklova 2016)

As will be shown, there is much evidence that Knossos was not able to keep the situation under control. It should be mentioned that almost all sites destroyed during LM IB suffered at least some disturbance in the LM IA period as well but then they survived, were rebuilt, re- 


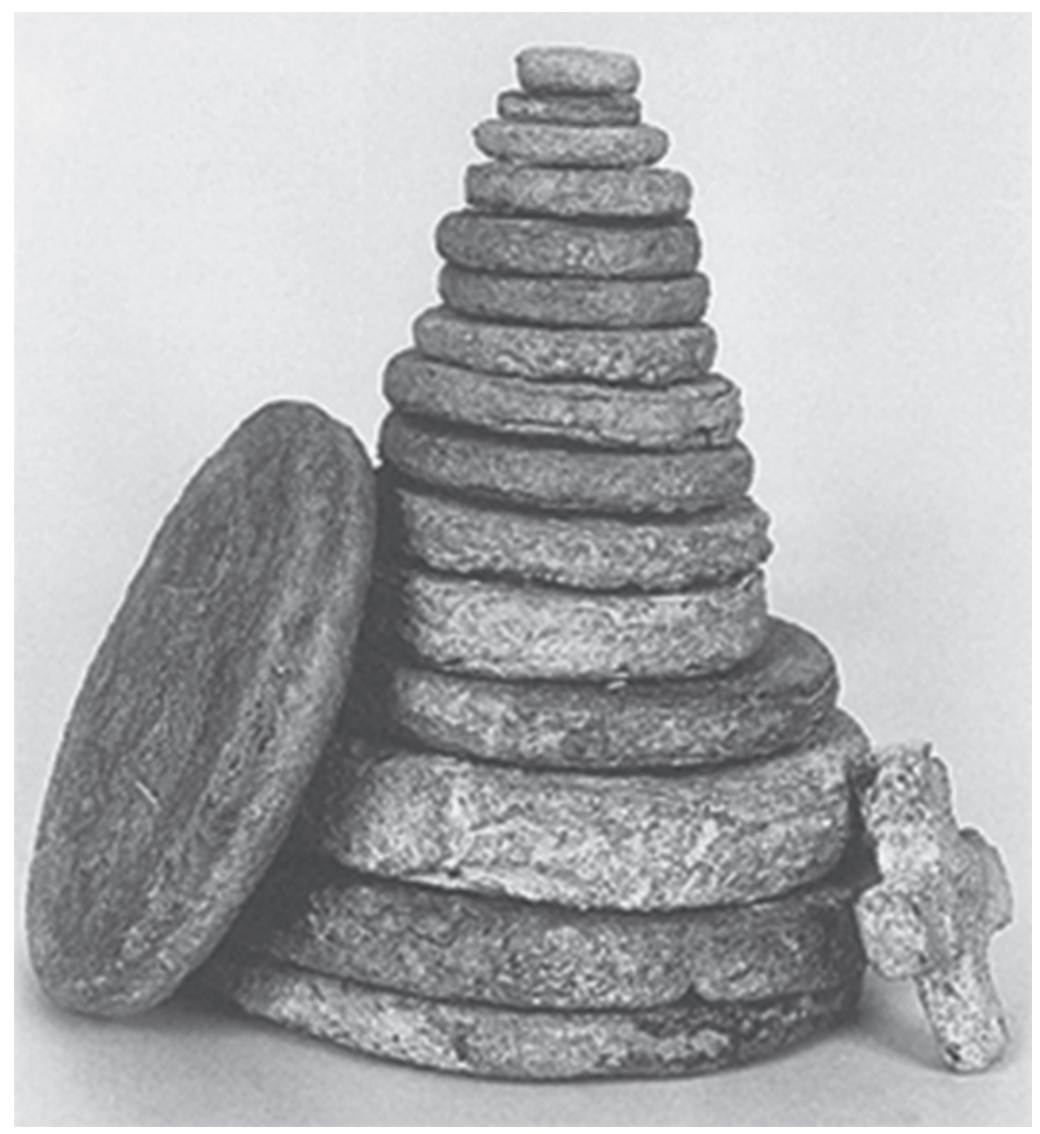

Fig. 11: Akrotiri (Santorini/Thera): set of lead weights (after Barber 1994, 193, fig. 136)

paired or reoccupied (Driessen and Macdonald 1997, 37) which implies that instability, competition and conflicts accompanied the process of the state's birth.

During the LM IB period, there is evidence of significant disruptions, and almost all Minoan centres, not only on Crete but also in the Cyclades, were destroyed (fig. 4). At many sites, abandonment follows burning, and many of the destroyed and abandoned sites were not resettled before the LM IIIA1-2 period. The destructions mark a more significant interruption of Minoan culture than those in MM II. They did not happen at the same time; the process took about 50 years (circa 1485-1425 BC). It seems that they started in the western part of the island, and that some of the centres were hit twice. Major destructions were documented in Chania and Nerokourou in the west, in Phaitsos and Hagia (Ayia) Triada in the South, and in Mochlos, Gournia, Pseira, Pyrgos, Makryialos, Petras, Paliakastro and Zakros in the East. Further destructions were documented in Zominthos, Sklavokampos, Tylissos, the Knossos area, Archanes, Amnisos, Nirou Chani and Malia in central Crete. Knossos palace is the only exception, having no identifiable major destruction during the whole LM I period, though even here several buildings around the palace were damaged and destroyed. In Kommos, only 
limited destruction of house X was documented. (fig. 4; Driessen - Macdonald 1997, 119-257, Soles 1999)

These destructions are not random, they appear to have been carefully planned to destroy as many administrative centres as possible. Settlements, and specifically buildings that housed Linear A administrations, were badly hit. There can be little doubt that they were deliberate targets. For example, in Pyrgos, the villa was burned down, but the surrounding town was left; at Mochlos, ashlar building B2 was destroyed, but not the Artisans' quarter, which continued into LM II.

Exceptionally good evidence for this was left after the attack on the Palaikastro centre, where the central shrine was destroyed and the process of this destruction could easily be reconstructed. Equipment was thrown to the floor, and the central ivory statue was taken by its base and smashed against the wall opposite. The internal space was filled with flammable material and oil, doors were sealed, and the shrine was burned. It probably exploded, destroying ashlar walls and spreading the contents of the room around. The other houses of Palaikastro were not affected. (Rehak and Younger 2001, 440-441; MacGillivray et al. 2000, 108-115; Cunnigham 2007, 29-43; Platon 1966, 157-159; 1971, Driessen - Macdonald 1997, 108-109; Klontza-Jaklová 2013, 241)

\section{Conclusions ${ }^{6}$}

It can be summarized that after the "wave" of destructions of the LM IB phase:

- There was a distinct decrease in settlements and in population

- United material culture crumbled away

- Material culture related to Knossian workshops and the Knossian cult, previously spread across the territory of Knossian influence, was no longer in use. Production was limited to a new smaller Knossian territory.

- Centres of the Knossian cult were abandoned. Later on the cult seems to be connected to regional centres, which seem to be more independent, operating according to their own economic and political programme.

- The administrative system no longer functioned (Weingarten 1990, 110; Driessen and Macdonald 1997, 77-78).

The Knossian central power was forced to resign its former hegemony over most of the island and recede into a smaller region, controlling only its immediate surroundings and a part of central Crete, which would point to wide spread rebellion(s) (Driessen - Macdonald 1997, 53, 97; Cunningham 2007, 42; MacGillivray 2009, 165; Klontza-Jaklová 2013, 282)

The local representatives of Knossian power were killed or thrown out of their residences. It seems that many of the inhabitants died or moved away from the island. It is likely that the land (and the economy) affected by the Santorini volcanic eruption, and by the ensuing rebellions, was not able to feed all the population.. Nevertheless, it remains an unsolved question why such a big decrease in population occurred (fig. 12).

The centralized power which had maintained control over almost the whole island during the previous period was destroyed, and, until Crete became part of the Roman Empire, such centralization was never re-established.

The Knossian Neopalatial state was not fully developed. The palace elite had, in practice, already started to assert political control during MM III, at least 200 years before the destructions occurred. However, the state structure that they created was not sufficiently solidly established to survive the crisis evoked by an ecological event. Joseph Tainter has described such 
collapses as "unsuccessful efforts" (Tainter 2009, 62). Although not fully developed even 'efforts' and segmentary states, as defined by Maisels or Knappett, can collapse. It seems that the Knossian state did not collapse because resources were immediately depleted, or even because the essential continuing demands on central resources exceeded the capacity to generate them. It probably collapsed because there was no solidly developed political, economic and ideological structure which would be able to withstand the moment of radical ecological crisis. Driessen and Macdonald document that "sometime in the mature LM IA, the building programmes stopped; a few monumental and prestigious buildings were not finished" $(1997,42)$. It is possible to consider that a certain economic inadequacy, which began to occur earlier in the LM IA period, had already undermined stabilitity.

However, the period of New Palaces is undoubtedly the most complex and controversial period of Aegean prehistory (Immerwahr 1990, 77).

The MMIII and LMIA period is the time when Crete left the phase of the confederation of chiefdoms or chieftainship and became what can be described as an early state. The process was apparently not fully concluded in all aspects. Centrifugal tendencies became fully apparent after the Santorini catastrophe. Evaluationn of the factors which prevailed is difficult for a period when there is no direct written evidence to illustrate some of the nonmaterial state characteristics.

\section{How did this process influence subsequent periods?}

The eras which followed are difficult to understand, because we still do not know exactly what happened in the LM IB period. But it seems very possible that the destruction of centralized power in effect allowed Crete in the LM IIIB period to withstand the destructive force of attackers coming from over the sea, and the Cretan centres (with only a few exceptions) were not as severely affected as the Mycenaean centres. The collapse of the central power system during LM IB probably allowed the population to find other solutions: most notably an organized change of settlement pattern, wherein coastal settlements were abandoned, and new "cities" were built in the mountains of the Cretan mainland. These settlements have most of the characteristics of later classical cities, probably even including the principles of democracy. Given the obvious 'equality', represented both in architecture and in material culture, we can exclude the possibility that the structures were built by people who were forced to do the work by and for privileged individuals (Wallace 2010, 52, 104 and further)

We have avoided hypothetical statements, such as 'If Knossos had managed to keep its hegemony over the island ...' However, the mainland centres - well fortified and well-organized though they were - did not survive the crisis in the $13^{\text {th }}$ century BC. It is therefore clear that the inhabitants of the Mycenaean polities are highly likely to have participated in the process of the destructions. (Yassur-Landau 2010, 223224; Cline 2014, 43-72)

Here, we must go back to the title of our paper: "If it was a state, it collapsed". All aspects confirm and justify its renaming: It was a state and it collapsed.

\section{Past, present and future}

What now? We should see if we can extract any message for today from the collapse of the Minoan Neopalatial system. We are scientists, not politicians, but our science must make sense, must be reasonable, and must give something to contemporary society. If some of the events 
we study are driven by deep-seated rules of human behaviour, they should also be valid today, we have a chance to test our theories. We can check what the people in the past did in circumstances similar to certain present day circumstances? Did their actions help at all? Did they understand at all what was going on around them? Do we have a chance to avoid an oncoming collapse? Or do we want a collapse, and do we want to accelerate it, so that new structures can be created? Can we predict what will come after? Which parts of society are healthy and will survive?
We are convinced that there is a message, that there are aspects of past experience that can be of use today, and that we can learn from them. Aegean Late Bronze Age society is a good example of how centralization of power and wealth by small groups of people, in just a few centres, can be both counterproductive and dangerous (to society, and also to the power elites).

The example of Crete shows the possibility that more democratic solutions can drive society forward toward "better times".

1) We further explain in the text why we consider the LM IA period in Crete to be a state. We used quotation marks because there is no consensus on this topic.

2) Different researchers use different adjectives for various reasons. We tend to favour the term EARLY STA$\mathrm{TE}$, as will be explained below.

3) "In the lineage-based society the step beyond the chiefdom is the segmentary lineage state. To the extent that it is segmentary it is structured as if every segment was a chiefdom in its own right, with its own internal hierarchy. To be called a state a segmentary state must have a king exercising hegemony over the segments. However to be a true state the king must gain control over the segments and reduce their relative autonomy, changing the system of stratification from one that is segment based and focused to one that is court based and focused. Only then can a monarch employ the apparatuses of power, characteristic of a developed state, that make his will felt throughout the kingdom. So a segmentry state is a transitional or stalled form."

4) Other bibliography to the topic: Branigan 1970, 1995, 2001; Laffineur-Niemeier 1995.

5) MM IIIB - MM IIIB/LM IA or LM IA Early = earthquake and some burnings

6) Detail overview of contemporary interetations in Klontza-Jaklová 2013, 237-295.

\section{Bibliography}

Arnold, V. I. 1992: Catastrophe Theory, 3rd ed. Berlin: Springer-Verlag.

Barber, R. L. N. 1994: Oi Kyklades stin Epochi tou Chalkou. Athens.

Bárta, M. 2011: Kolaps a regenerace: pokračující cesty minulých civilizací. In: Bárta and Kovář (eds.), 19-48.

Bárta, M. Kovářr, M. 2011 (eds.): Kolaps a regenerace: cesty civilizací a kultur: minulost, současnost a budoucnost komplexních společností. Praha.

Bietak, M. Marinatos, N. - Palyvou, C. 2007: Taureador Scenes at Avaris and Knossos. Wien.

Blanton, R. - Fargher, L. (eds.) 2008: Collective Action in the Formation of Pre-Modern States. Springer: New York.
Branigan, K. 1970: The Foundation of Palatial Crete. A Survey of Crete in the Early Bronze Age. States and Cities of Ancient Greece. London.

Branigan, K. 1995: Social Transformations and the Rise of the State in Crete. In Laffineure and Niemeier (eds.), 33-40.

Branigan, K. (ed.) 2001: Urbanism in the Aegean Bronze Age. Shefield, Shefield Studies in Aegean Archaeology 4.

Charvát, 2011: Každý konec je nový začátek: transformace sumerské společnosti na přelomu 4. a 3. tisíciletí př. n. 1. In: Bárta and Kovář (eds.), 187-210.

Claessen, H. J. M. - Skalnik, P. 1982: The Early State. Models and Reality. In Early State, 637-650.

Cline, E. 2014: 1177 B.C.: The Year Civilization Collapsed. Princeton: Princeton University Press. 
Cohen, R. - Service, E. R. (eds.) 1978: Origins of the State. The Anthropology of Political Evolution. Institute for the Study of Human Issues: Philadelphia.

Cunningham, T. 2007: HAVOC: The Destruction of Power and the Power of Destruction in Minoan Crete. In: Bretschneider, J., J. Driessen and K. Van Lerbergie (eds.): Power and Architecture. Monumental Public Architecture in the Bronze Age Near East and Aegean. Proceedings of the internatioanl conference Power and Architecture, organized by the Katholieke Universiteit Leuven, the Université Catholique de Louvain and the Westfälische Wilhelms-Universität Münster, November $21^{\text {st }}$ and $22^{\text {nd }}, 2002$. Orientalia Lovaniensia Analecta 156, Leuven, Paris, Dudley, MA. 23-43.

D'Altroy, T. - Earle, T. 1985: Staple finance, wealth finance, and storage in the Inca political economy. Current Anthropology 26 (2), 187-206.

Decker, M. J. 2016: The Byzantine Dark Ages. Bloomsburry Academic. Bloomsburry, London, Oxford, New York, New Dehli, Sydney.

Desborough, V. R. d'A. 1972: The Greek Dark Ages. London. Ernst Benn.

Doumas, C. 1992: The Wall-Paintings of Thera. The Thera Foundation. Athens.

Driessen J. - Macdonald, C. F. 1997: The Troubled Island. Minoan Crete before and after the Santorini eruption. Aegeum 17. Annales d'archéologie égéene de l'Université de Liège et UT-PASP. Liège and Austin, Texas.

Earle, T. 1989: The evolution of chiefdoms. Current Anthropology 30. 84-88.

Earle, T. 1991: Chiefdoms: Power, Economy, and Ideology. Cambridge University Press: Cambridge, New York, Port Chester, Melbourne, Sydney.

Eisenstadt, S. 1991: Beyond Collapse. In Yoffee, N. Cowgill, G. L. (eds.): The Collapse of Ancient States and Civilisations. Tuscon.

Evans, A. J. 1909: Scripta minoa: the written documents of minoan Crete with special reference to the archives of Knossos (Band 1): The hieroglzphic and primitive linear classes. Oxford.

Feinman, G. M. - Marcus, J. 1998 (eds.): Archaic States. School of American Research Press: Santa Fe.

Feinman, G. M. - Neizell, J. 1984: Too many types: an overview of sedentary prestate societies in the Americas. Advances in Archaeological Method and Theory 7, ed. By M. Shiffer, 39-102. New York: Academic Press.

Flannery, K. V. 1998: The Ground Plans of Archaic States. In Feinman and Marcus (eds.), 15-57.

Fried, M. H. 1960: On the evolution and social stratification of the states. In: Diamond, S (ed.): Culture in History, Columbia University Press, 713-731.

Haas, J. 1982: The evolution of the Prehistoric State. Columbia University Press: New York.

Immerwahr, S. A. 1990: Aegean painting in the Bronze Age. University Park: Pennsylvania State University Press.

Klontza-Jaklová, V. 2008: Datierung der Katastrophe von Santorini. Kurze Zusammenfassung des bisherigen Standes der Forschung und vorherrschende Tendenzen. Anodos. Studies of the Ancient World, Trnava: Trnavská univerzita, 2008, $8 / 4,13-57$

Klontza-Jaklova, V. 2013: Studie k historickým interpretacím pozdní doby bronzové v Egejdě. Late Bronze Age in Aegean:

Study in Historical Interpretations. Disseratation. Faculty of Arts. Charles University. Prague. https:// is.cuni.cz/webapps/zzp/detail/101604/?lang=en

Klontza-Jaklova, V. 2015: The LM IB "Hoarding Horizon” On Crete (An Essay). Bátora, J. and P. Tóth, P. (eds.): Ked' bronz vystridal med'? Zborník príspevkov z XXIII. medzinárodného sympózia,,Staršia doba bronzová v Čechách, na Morave a na Slovensku“ Levice 8.-11. októbra 2013. Archaeologica Slovaca Monographiae. Communicationes. Instituti Archaeologici. Academiae Scientiarum Slovacae. TOMUS XVIII. Bratislava, Nitra. 373-390.

Klontza-Jaklová, V. 2016: What's wrong? Hard science and humanities solving the question of absolute chronology of Santorini volcano Bronze Age eruption. Nakladatelství Masarykovy univerzity.

Klontza-Jaklova, V. and Klontzas, M. (in press) 2019:

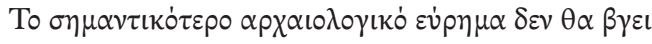
$\alpha \pi \dot{0} \tau \eta \nu \gamma \eta$. Athens.

Knappett, C. 1999: Assessing a Polity in Protopalatial Crete: The Malia-Lasithi State. AJA 103, 615-39.

Kristiansen, K. 1991: Chiefdoms, States, and systems of social evolution. In Earle (ed.), 16-43.

Laffineur, R. - Niemeier, W.-D. (eds.) 1995: POLITEIA: Society and State in the Aegean Bronze Age. Aegeum 12. Liège and Austin. 
MacGillivray, J. A. 2009: Thera, Hatshepsut, and the Keftiu: crisis and response in Egypt and the Aegean in the mid-second millenium BC. In: Warburton, D. A. (ed.): Time's Up! Dating the Minoan Eruption of Santorini. Acts of the Minoan Eruption Chronology Workshop, Sandbjerg November 2007 initiated by Jan Heinemeier \& Walter L. Friedrich. Aarhus. 154-170.

MacGillivray, J. A. - Sackett, L. H. - Driessen, J. 2000 (eds.): The Palaikastro Kouros: A Minoan Chrysellephantine Statuette and its Aegean Bronze Age Context. BSA studies. Athens.

Maisels, C. 2010: The Archaeology of Politics and Power. Where, When and Why the First States Formed. Oxford and Oakville: Oxbow Books.

Marcus, J. - Feinman, G. M. 1998: Introduction. In Feinman and Marcus (eds.), 3-13.

Marinatos, N. 1993: Minoan Religion. Ritual, Image and Symbol. Columbia.

Marx, K. 1857: Pre-capitalist economic formations, https://www.marxists.org/archive/marx/ works/1857/precapitalist/ch01.htm (April 19th 2019)

Melas, M. 1988: Minoans Overseas: Alternative models of Interpretation, Aegeum 2, 47-70.

Michailidou, A. 2001a: Script and metrology: practical processes of cognitive inventions. In: Michailidou ed. $2001,43-82$.

Michailidou, A. 2001b: Recording quantities of metal in Bronze Age societies in the Aegean and the Near East. In: Michailidou ed. 2001 , 85-119.

Michailidou, A. (ed.) 2001: Manufacture and Measurement, Counting, Measuring and Recording: Craft Items from Early Aegean Societies. Athens. Meletemata 33. Research Centre of Greek and Roman Antiquity - National Hellenic Research Foundation.

Molloy, B. P. C. 2002: Martial Minoans? War as a social proces, practise and event. In: Bronze age Crete. The Annual of the British School at Athens, 107, 87-142

Morgan, L. 1988: The miniature wall paintings of Thera. A Study in Aegean culture. Cambridge Classical Studies. Cambridge, New York, New Rochelle, Melbourne, Sydney.

Moseley, K. and Wallerstein, I. 1978: Precapitalist Social Structures. Annual Review of Sociology, 4, 259-290.
Nowicki, K. 2000: Defensible Sites in Crete c. 1200800 B.C. (LM IIIB/IIIC through Early Geometric). Aegeum 21.

Pendlebury, J. D. S. 1939: The Archaeology of Crete. An Introduction. London.

Pfeiffer, J. E. 1977: The Emergence of Society: a Prehistory of the Establishment. McGraw-Hill, New York.

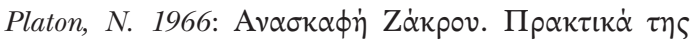

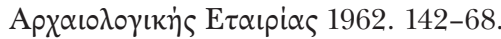

Platon, N. 1971: Zakros. The Discovery of a Lost Palace of Ancient Crete. New York.

Poston, T. - Stewart, I. 1998: Catastrophe: Theory and Its Applications. New York: Dover.

Rehak, P. Younger, J. 2001: Review of Aegean Prehistory VII: Neopalatial, Final Palatial, and Postpalatial Crete. In: Cullen, T. (ed.): Aegean Prehistory: A Review. AJA Suppl. 1. Boston: Archaeological Institute of America. 383-473.

Sanders, W. T. - Webster, D. 1978: Unilinealism, multilinealism, and the evolution of complex societies. In Redman, C. L. Berman, M. J. Curtin, V. Langhorne, W. T. Jr., Versaggi, N. M. and Wanser, J. C. (eds.): Social Archaeology: beyond subsistence and dating. Academic Press: New York, 87-90.

Sanns, W. 2000: Catastrophe Theory with Mathematica: A Geometric Approach. Germany: DAV.

Saunders, P. T. 1980: An Introduction to Catastrophe Theory. Cambridge, England: Cambridge University Press

Service, E. 1977: The Origin of the State and Civilization. New York: Norton.

Shelmerdine, C. W. (ed.) 2008: The Cambridge Companion to the Aegean Bronze Age. CambridgeNew York-Melbourne-Madrid-Cape Town-Singapore-Sao Paulo-Delhi.Sloman, S. 2005: Causal Models. How People Think about the World and its Alternatives, Oxford.

Soles, J. S. 1995: The Functions of a Cosmological Centre: Knossos in Palatial Crete. In: R. Laffineur and W. D. Niemeier (eds.).405-414.

Soles, J. S. 1999: The Collapse of Minoan Civilisation. In: R. Laffineur (ed.): Polemos. Le contexte guerrier en Égée á l'age du bronze. Actes de la 7e Rencontre égéenne internationale Université de Liège, 14-17 April 1998. Liège; Austin 1995, 57-65. 
Snodgrass, A. 1971: The Dark Age of Greece. Edinburgh. Edinburgh University Press.

Spencer, C. 1987: Rethinking the chiefdom. In: Drennan, R. D. and Uribe, C. A. (eds.): Chiefdoms in the Americas. University Press of America: Lanham, MD. 369-390.

Tainter, J. A. 2009: Kolapsy složitých situací. Praha. (Original edition: 1988 The collapse of complex societies Cambridge University Press Cambridge, New York)

Upham, S. 1987: A theoretical consideration agriculture in Kohala, Hawaii. Journal of Field Archaeology 7, 297-312.

Wallace, S. 2010: Ancient Crete. From Successful Collapse to Democracy's Alternatives, Twelfth to Fifth Centuries BC. Cambridge University Press: Cambridge.

Weingarten, J. 1990: Three Upheavals in Minoan Sealing Administration: Evidence for Radical Change. In: Palaima, T. G. (ed.): Aegean Seals, Sealings and Administration. Proceedings of the NEHDickson Conference of the Program in Aegean Scripts and Prehistory of the Department of Clas- sics, University of Texas at Austin, January 11-13, 1989. Aegaeum 5. Annales d'archéologie égéenne de l'Université de Liège. Université de Liège, Histoire de l'art et archéologie de la Grèce antique. Université de Liège. 105-120.

Wiener, M. 2013: Realities of Power: The Minoan Thalassocracy in Historical Perspective. In: R. Koehl (Ed.), Amilla: The quest for excellence : Studies presented to Guenter Kopcke in celebration of his 75th birthday (pp. 149173). Philadelphia, PA: INSTAP Academic Press (Institute for Aegean Prehistory).

Wright, J. C. 2008: Early Mycenaean Greece. In: Shelmerdine (ed.), 230-257.

Wright, H. T. 1977: Recent Research on the Origin of the State. Ann. Rev. Anthopol. 6, 379-97.

Yassur-Landau, A. 2010: The Philistines and Aegean migration at the end of the late Bronze Age. Cambridge University press. New York.

Younger, J. G. - Rehak, P. 2008: The Material Culture of Neopalatial Crete. In Shelmerdine (ed.), 140164. 


\section{Resumé}

Cílem článku je diskuse př́ičin kolapsu knosského centralizovaného (raného) státu, jeho možného průběhu, ale také zda symptomy kolapsu obsažené v archeologických kontextech mohou sloužit jako vodítka pro rekonstrukci forem struktur, které zkolabovaly. Kolapsem rozumíme proces destrukce více nebo méně komplexní struktury, $\mathrm{v}$ daném případě politicko-ekonomické. Kolaps může mít variabilní rozsah a intenzitu v čase a prostoru. Může být hodnocen subjektivně na základě úhlu pohledu pozorovatele nebo proživatele. Má však také objektivní hodnotu, která je vyjádřitelná (v některých aspektech) matematicky. Kolaps je přirozenou součástí přírodních a společenských procesů. Ruší nefunkční struktury, vztahy a mechanismy, aby uvolnil prostor pro nové (např. Pfeifer 1977; Saunders 1982; Eisenstadt 1991; Arnold 1992; Poston and Steward 1998; Sanns 2000; Tainter 2009; Wallace 2010; Bárta 2011; Charvát 2011).

Chování lidí v rámci konkrétního systému, stejně jako jejich reakce (na individuální i kolektivní úrovni) na krizové situace není sice uniformní, ale vykazuje určité pravidelnosti, řídí se zákonitostmi, které je možné předem definovat, stejně jako míru pravděpodobnosti každé možné reakce té které společnosti (Tainter 2009, 63-64; Bárta 2011, 23, 29 ad.).

Obvyklý způsob studia procesu kolapsu komplexních společností začíná definicí státních struktur a dynamiky, která je vytvořila. Následuje analýza procesu kolapsu. Zde aplikujeme obrácený postup: v archeologických kontextech pozdně minojského období stupňů IA a IB (LM IA, LM IB, Obr. 1: chronologická tabulka egejské doby bronzové) jsou definovány doklady kolapsu a na jejich základě je modelováno, jak mohla vypadat komplexita struktury/systému, který zkolaboval. Byla zvolena tato metoda, protože o studované struktuře existuje pouze omezené množství primárních i sekundárních pramenů. Je testováno, zda se jednalo o společnost předstátní, tedy operující v systému náčelnictví, nebo o společnost raného státu.

V průběhu období LM IB probíhaly destrukce administrativních center, které následovaly období katastrofické erupce santorinského vulkánu na přelomu období LM IA/IB (Klontza-Jaklová 2016). Tyto destrukce probíhaly v průběhu zhruba 80 let; v drtivé většině př́ípadů byl původcem člověk; mírily pouze na administrativní centra, konkrétně jejich centrální struktury (přehled interpretačních teorií: Klontza-Jaklová 2013, 281-294).

Tato zničená centra (krom Knossu, který napadený nebyl) zůstala opuštěná a v rozvalinách po dobu nejméně 50 let a osídlení se na ně vrátilo (v úplně jiné formě) až v období LM IIIA (Obr. 2: lokality zmíněné v textu, Obr. 3: úbytek sídel od LM IA do LM IIIA období).

Diskuse o existenci státu na Krétě doby bronzové (minojské období) začala již v 60. letech 20. století a kulminovala na konci 20. století (Knappett 1999).

Vznik státu je dlouhodobý a komplikovaný proces. Na Krétě jej můžeme detekovat od rané doby bronzové (Obr. 4). V protopalácovém období existovaly na Krétě palácové politie, které měly ve vrcholných momentech formu velmi raných státních útvarů a mohly být patrně propojené $\mathrm{v}$ náčelnickou konfederaci, jak ji definuje D. B. Gibon (2011). V tomto období rapidně narůstá společenská komplexita a období vrcholí destrukcemi paláců, které byly následně rychle přestavěny podle knosského vzoru. Začíná tzv. novopalácové období (MM III - LM IA), které následně prokazuje známky centralizovaného státu (s centrem v paláci Knossos), jak bylo definován v mnoha teoretických pracech (např. Marx 1857; Wright 1977; Moselley and Wallenstein 1978; Claessen and Skalnik 1982; Haas 1982; Kristiansen 1991; Feinman and Marcus 1998; Blanton and Fargher 2008; Maisels 2010):

- společnost rozdělená do dvou vrstev (vládnoucí a podřízené) s vládcem, jehož postavení bylo zdůvodněno mytologicky

- nejméně čtyřstupňová hierarchie center s jedním hlavním (Obr. 5)

- existence státní administrativy a daní (Obr. 6)

- státní ideologie zdůvodňující status quo (Obr. 7)

- vojsko pro použití uvnitř i vně (Obr. 8)

- zákony, pravidla a dopady v případě jejich nedodržování

- teritorium (Obr. 9)

- obchod na velké vzdálenosti kontrolovaný vládnoucím centrem

- diplomatické vztahy, zahraniční politika (Obr. 10) 
- monetární a jednotkový systém (Obr. 11)

- budování státních tvrdých a měkkých struktur (Service 1977; Wright 1977; Cohen and Service 1978; Claessen and Skalnik 1982; Haas 1982;

Tyto prvky jsou sledovatelné $\mathrm{v}$ archeologickém materiálu právě v období následujícím destrukce LM IB stupně. Tehdy jsou patrné změny prakticky ve všech aspektech. Lokální centra se osamostatňují, mizí písmo a administrativa, jsou opuštěny svatyně knosského typu, hmotná kultura produkovaná knosskými dílnami není dále šířena po ostrově, jednota hmotné kultury se rozpadá, ubývá importů z Egypta ad. Knossos sice zůstal důležitým centrem, ale patrně se musel spokojit $\mathrm{s}$ výrazně menším teritoriem a postupně se zařadit do nového uspořádání světa období, které nazýváme mykénským.

At̉ už byla forma novopalácového státu na Krétě jakákoliv, jednalo se o raný centralizovaný stát, jehož struktury byly velmi slabé a snadno podlehly odstředivým silám, které doprovázely a následovaly krizi akcelerovanou santorinskou erupce. Její dopady na Krétu patrně zpochybnily kompetence vládnoucí složky a došlo $\mathrm{k}$ decentralizaci ve všech směrech, i když pozvolný proces projevů krize je možné pozorovat již během samotného období LM IA, tedy před erupcí vulkánu.

LM IA stát na Krétě je prvním centralizovaným státním útvarem v Evropě. Jednalo o nejkomplexnější společenské uspořádání Evropy doby bronzové a je možné jej popsat jako tzv. raný stát.

Také jsme přesvědčeni o tom, že studium kolapsů a společensko-ekonomických cyklů může napomoci dešifrovat určující síly i v současné situaci, kdy i přes vyspělou technologii jsme pořád součástí společenského cyklu, který započal právě se vznikem prvních států. 


\section{Věra Klontza-Jaklova}

- Institute of Archaeology and Museology, Faculty of Arts, Masaryk University

Arne Novak Str. 1, CZ 60200 Brno

verakj@mail.muni.cz

\section{Manolis Klontzas}

- Institute of Archaeology and Museology, Faculty of Arts, Masaryk University

Arne Novak Str. 1, CZ 60200 Brno

418374@mail.muni.cz 